\title{
ANTIOXIDANTS ACTIVITIES OF SECONDARY METABOLITE COMPOUNDS FROM BUNI FRUIT (Antidesmabunius L.) SEED EXTRACT
}

\author{
M. Yasser ${ }^{\bowtie}$, A.M.I.A Asfar and S.E. Widiyanti \\ Department of Chemical Engineering, Politeknik Negeri Ujung Pandang, Makassar-90254, \\ South Sulawesi, Indonesia \\ Corresponding Author: myasser@poliupg.ac.id
}

\begin{abstract}
In this study, methanol solvent was used to extract the seeds of Buni fruit with Ultrasound-Assisted Extraction at a temperature of $50^{\circ} \mathrm{C}$ for 45 minutes. The methanol extract of Buni fruit seeds produced two phenolic compounds because of characterization using GCMS, namely Eugenol and Alpha-Tocopherol-beta-D-mannoside. The resulting IR spectrum showed the presence of a hydroxyl group $(-\mathrm{OH})$ and aromatic compounds in the methanol extract of buni fruit seeds. Total Phenolic Content of Buni fruit seed methanol extract was $38.667 \pm 0.764 \mathrm{mg} / \mathrm{g}$ in GAE (Gallic Acid Equivalent) and Antioxidant Activity $\mathrm{IC}_{50}$ was $11.632 \pm 0.280 \mathrm{mg} / \mathrm{L}$. The high antioxidant content of the methanol extract of buni fruit seeds has the potential to be used as a healthy food ingredient for the body.
\end{abstract}

Keywords: Antioxidant, Total Phenolic Content, Extraction, Methanol, The Seed of Buni Fruit.

RASĀYAN J. Chem., Vol. 14, No.2, 2021

\section{INTRODUCTION}

Plants that are included in the Antidesma genus-group are known to have health properties such as antimicrobials and antioxidants. ${ }^{1-3}$ Buni fruit (Antidesmabunius L.) is one of the plants belonging to the Antidesma genus. Buni fruit is one of the plants used as a traditional medicinal plant in the Bugis tribe in Indonesia. Exploiting every part of the plant has the potential to be used as a source of natural medicine. Several studies have only developed Buni fruit pulp and Buni fruit water as a potential part of being used as a source of treatment., ${ }^{2,4}$

Buni plants consist of several parts such as leaves, stems, meat, and seeds. Buni fruit seeds are part of the buni fruit whose utilization has not been found much, even only used as a byproduct of the buni fruit, even though every part of a plant is believed to have properties because it contains secondary metabolites. Secondary metabolite compounds in the form of phenolic compounds in plants have the potential to be used as antioxidants because of their ability as electron donors that are in their hydroxyl groups so that they can ward off free radicals. ${ }^{6,7}$

Optimization of the potential utilization of the seeds from the Buni fruit needs to be developed as an antioxidant because, in addition to the abundant amount, the seeds of the Buni fruit must contain secondary metabolite compounds. For this reason, this study aims to characterize the secondary metabolite compounds contained in the methanol extract from the seeds of Buni fruit and to determine their potential antioxidant activity. Buni fruit seeds are extracted using Ultrasound-Assisted Extraction because the process is easy and fast but does not affect the quality of the extract produced. ${ }^{8,9}$

\section{EXPERIMENTAL}

\section{Reagent}

All chemicals used to come from the Merck company such as methanol $\left(\mathrm{C}_{2} \mathrm{H}_{5} \mathrm{OH}\right)$, Folin-Ciocalteau Phenol, Sodium Carbonate $\left(\mathrm{Na}_{2} \mathrm{CO}_{3}\right)$, Gallic Acid, while the chemicals that come from the Sigma Aldrich company are 2,2-diphenyl-1-picrylhydrazyl (DPPH). 
RASĀYAN J. Chem.

Vol. 14 | No. 2 |1351-1355| April - June | 2021

\section{Extraction of Buni Fruit Seeds}

The purplish-red color of the Buni fruit plant material from inside and around the Moncongloe-Maros area, Indonesia is collected, washed, separated between the meat and seeds then dried, and made into powder for further extraction.

The extraction of buni fruit seeds was carried out using the Ultrasound-Assisted Extraction method using methanol as a solvent. 300 grams of Buni seed powder that has been dissolved with methanol are then put into Ultrasound-Assisted Extraction at a temperature of $50^{\circ} \mathrm{C}$ with a soaking time of 45 minutes with a wave of $40 \mathrm{KHz}$. The resulting filtrate is then evaporated at low pressure and a temperature of less than $45^{\circ} \mathrm{C} .^{6}$

\section{Chemical Analysis of The Extract}

To determine the content of the bound functional groups, the methanol extract from the seeds of Buni fruit was characterized using Infrared Spectroscopy (Prestige-21 Shimadzu Infrared spectroscopy), while to determine the composition of the compounds contained in the methanol extract from the seeds of Buni fruit, measurements were carried out using GCMS (Ultra Shimadzu QP2010 Gas Chromatograph Mass Spectrometer). ${ }^{2,10,11}$

\section{Determination of Total Phenolic Content}

The solution containing a mixture of $1 \mathrm{~mL}$ of methanol extract from the seeds of Buni fruit was added with $1 \mathrm{~mL}$ of Folin Ciocalteau and $5 \mathrm{~mL}$ of $10 \% \mathrm{Na}_{2} \mathrm{CO}_{3}$ and then incubated at room temperature for 1 hour. Furthermore, the absorbance measurement of the mixed solution was carried out at a wavelength of $765 \mathrm{~nm}$ using UV-Vis Spectroscopy (Orion Aquamate 8000).Total Phenolic Content is obtained from plotting the absorbance of the sample in the calibration curve of the standard solution of gallic acid (range from 5 to $65 \mathrm{mg} / \mathrm{L}$ ) expressed as Gallic Acid Equivalent per gram (GAE / g). ${ }^{1,12,13}$

\section{Antioxidant Activity Test}

The methanol extract of the seeds of the Buni fruit was measured using the DPPH method., ${ }^{2,14,15} 2 \mathrm{~mL}$ of methanol extract of Buni fruit seeds at concentrations of 10,20,30, 40 and $50 \mathrm{mg} / \mathrm{L}$ were added each with $2 \mathrm{~mL}$ of $0.1 \mathrm{M} \mathrm{DPPH}$ into the test tube. The absorbance of the solution was measured by UV-Vis Spectroscopy at a wavelength of $517 \mathrm{~nm}$.

\section{RESULTS AND DISCUSSION}

The methanol extract of Buni fruit seeds was analyzed qualitatively using GCMS and Infrared Spectroscopy to determine the chemical compounds contained in the extract. The results of measurements using GCMS (Fig.-1 and Table-1), obtained secondary metabolite compounds included in the phenolic compound group, namely Eugenol (Fig.-4) and Alpha-Tocopherol-beta-D-mannoside (Fig.-5).

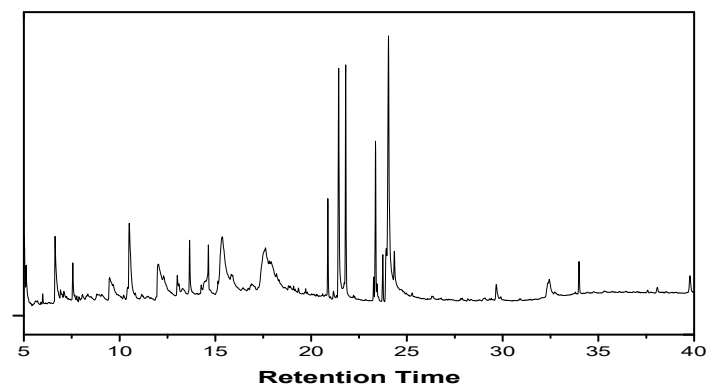

Fig.-1: Chromatogram of Measurement Results of Methanol Extract from Buni Fruit Seeds using GCMS

Table-1: Measurement Results with GCMS from Methanol Extract of Buni Fruits Seed

\begin{tabular}{c|c|l}
\hline No & Retention Time & Name of Compound \\
\hline 1 & 6.627 & 1,2-Cyclopentanedione \\
\hline 2 & 7.552 & 2,4-Dihydroxy-2,5-dimethyl-3(2H)-furan-3-one \\
\hline
\end{tabular}


RASĀYAN J. Chem.

Vol. 14 | No. 2 |1351-1355| April - June | 2021

\begin{tabular}{|c|c|c|}
\hline No & Retention Time & Name of Compound \\
\hline 3 & 10.503 & 4H-Pyran-4-one, 2,3-dihydro-3,5-dihydroxy-6-methyl- \\
\hline 4 & 12.012 & 2-Furancarboxaldehyde, 5-(Hydroxymethyl)- \\
\hline 5 & 12.294 & 1-Propanamine, 3-propoxy- \\
\hline 6 & 13.008 & Eugenol \\
\hline 7 & 13.654 & Eugenol \\
\hline 8 & 14.408 & 2-Butanone, 4-(3-Ethyloxiranyl)-, Trans- \\
\hline 9 & 14.636 & Caryophyllene \\
\hline 10 & 15.362 & Ethanol, 2-(2-butoxyethoxy)-, acetate \\
\hline 11 & 17.618 & 3-Deoxy-d-mannoic lactone \\
\hline 12 & 20.877 & Hexadecanoic Acid, Methyl Ester \\
\hline 13 & 21.441 & 1-(+)-Ascorbic acid 2,6-dihexadecanoate \\
\hline 14 & 21.725 & 5-Tetradecen-1-ol, acetate, $(Z)$ - \\
\hline 15 & 21.807 & Hexadecanoic Acid, Ethyl Ester \\
\hline 16 & 23.360 & 8,11,14-Docosatrienoic acid, methyl ester \\
\hline 17 & 23.739 & Octadecanoic acid, methyl ester \\
\hline 18 & 23.921 & 9,12-Octadecadienoic acid (Z,Z)- \\
\hline 19 & 24.040 & 9,12,15-Octadecatrien-1-OL \\
\hline 20 & 24.342 & Octadecanoic acid \\
\hline 21 & 29.668 & Hexadecanoic Acid, 2-Hydroxy-1-(Hydroxymethyl)Ethyl Ester \\
\hline 22 & 32.358 & 9-Octadecenoic Acid (Z)-, Octadecyl Ester \\
\hline 23 & 32.432 & 9,12,15-Octadecatrienoic acid, ethyl ester, (Z,Z,Z)- \\
\hline 24 & 33.988 & 2,6,10,14,18,22-Tetracosahexaene, 2,6,10,15,19,23-hexamethyl-, (all-E)- \\
\hline 25 & 39.780 & alpha.-Tocopherol-.beta.-D-mannoside \\
\hline
\end{tabular}

The content of phenolic compounds contained in the methanol extract of Buni fruit seeds was also strengthened from the results of qualitative analysis using IR spectroscopy which indicated the presence of a typical spectrum (Fig.-2) for aromatic groups at wave number $1454.38 \mathrm{~cm}^{-1}$ as $\mathrm{C}=\mathrm{C}-\mathrm{C}$ (aromatic) bonds and the hydroxyl group - $\mathrm{OH}$ at wave number $3387.11 \mathrm{~cm}^{-1} .{ }^{16-18}$

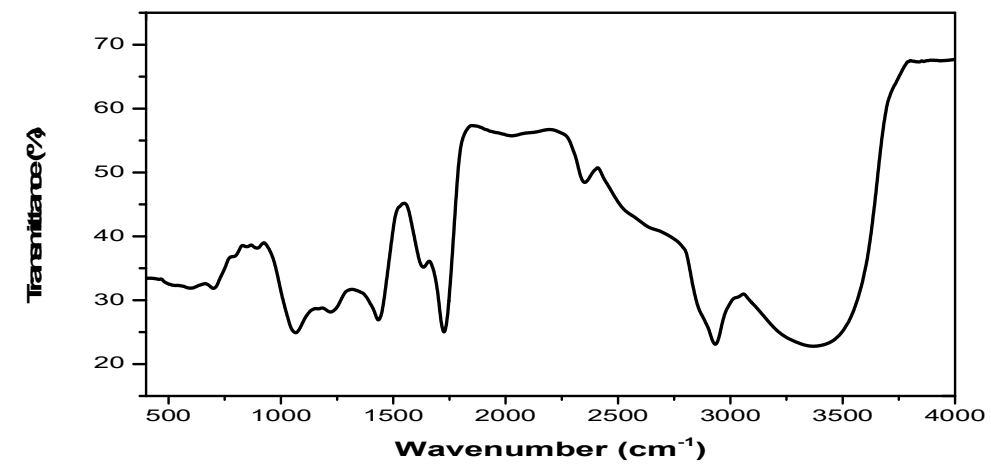

Fig.-2: Spectrum of Measurement Results of Methanol Extract from Buni Fruit Seeds using IR Spectroscopy

The content of Eugenol and Alpha-Tocopherol-beta-D-mannoside compounds in the methanol extract of Buni fruit seeds greatly impacts the total phenolic content and antioxidant activity. The results of Total Phenolic Content (Fig.-3 and Table-2) in the methanol extract of Buni fruit seeds were 38.667 \pm 0.764 $\mathrm{mg} / \mathrm{g}$ in GAE (Gallic Acid Equivalent) with $\mathrm{IC}_{50}$ Antioxidant Activity of $11.632 \pm 0.280 \mathrm{mg} / \mathrm{L}$.

According to Bezzera, et al. ${ }^{19}$ stated that Eugenol has many benefits such as being able to act as an antioxidant or prooxidant agent. In addition, it has anti-carcinogenic, cytotoxic and anti-tumor properties. While the Alpha-Tocopherol compound is known apart from being an antioxidant Alpha-Tocopherol is also useful as a treatment in Alzheimer's ${ }^{20}$ disease and anti-inflammatory disease. ${ }^{21}$ The ability of eugenol ${ }^{22-25}$ and Alpha-Tocopherol as an antioxidant is because eugenol is included in a group of phenolic compounds with characteristic aromatic rings. ${ }^{24}$ The presence of a hydroxyl group attached to the aromatic ring of phenol makes eugenol and Alpha-Tocopherol able to act as hydrogen donors to increase 
RASĀYAN J. Chem.

Vol. 14 | No. 2 |1351-1355| April - June | 2021

oxidation inhibition. ${ }^{26}$ The methanol extract of Buni fruit seeds is very strong in inhibiting $50 \%$ free radicals. It is included in the very strong antioxidant group because it has an $\mathrm{IC}_{50}$ of $<50 \mathrm{mg} / \mathrm{L}$. 2,27-29

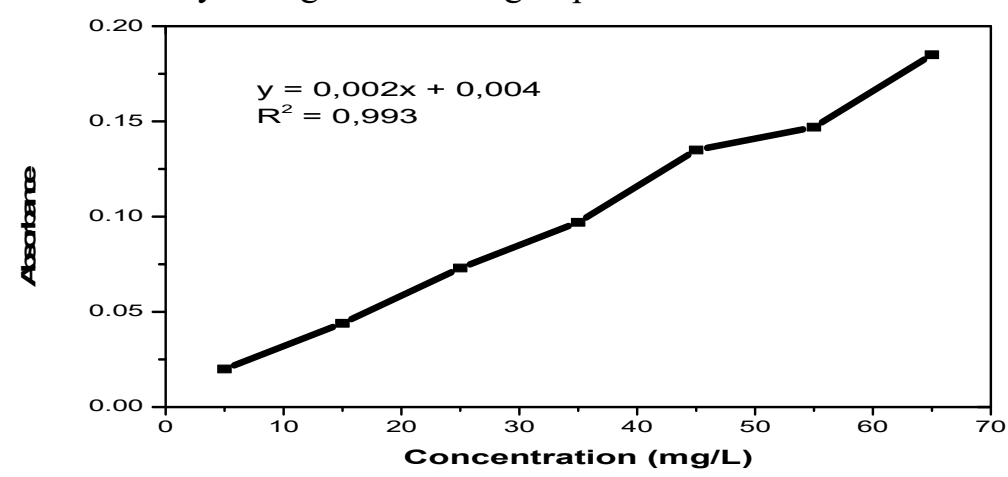

Fig.-3: The Standard Curve of the Measurement Results of Gallic Acid Solution at a Concentration of 5 ppm - 65 ppm

Table-2: Total Phenolic Content of Methanol Extract from Buni Fruits Seed

\begin{tabular}{c|c|c}
\hline Samples $^{*}$ & Absorbance & Total Phenol Content $(\mathrm{mg} / \mathrm{g}$ in GAE*) \\
\hline S1 & 0.083 & \multirow{2}{*}{$38.667 \pm 0.764$} \\
\hline S2 & 0.080 & \\
\hline S3 & 0.081 & \\
\hline
\end{tabular}

Table-3: Antioxidant Activities of Methanol Extract from Buni Fruits Seed

\begin{tabular}{c|c|c|c|c}
\hline Samples $^{*}$ & Linear Equations & $\mathrm{R}^{2}$ & $\mathrm{IC}_{50}(\mathrm{mg} / \mathrm{L})$ & Average of $\mathrm{IC}_{50}(\mathrm{mg} / \mathrm{L})$ \\
\hline S1 & $\mathrm{y}=0.097 \mathrm{x}+48.88$ & 0.994 & 11.5464 & \multirow{2}{*}{$11.6320 \pm 0.280$} \\
\cline { 1 - 3 } $\mathrm{S} 2$ & $\mathrm{y}=0.108 \mathrm{x}+48.71$ & 0.991 & 11.9444 & \\
\cline { 1 - 3 } $\mathrm{S} 3$ & $\mathrm{y}=0.121 \mathrm{x}+48.62$ & 0.996 & 11.4050 & \\
\hline
\end{tabular}<smiles>C=CCc1ccc(C)c(OC)c1</smiles>

Fig.-4: Eugenol<smiles>Cc1c(C)c2c(c(C)c1COC1OC3OC(OC(CO)C3O)C1CO)OC(C)(CCCC(C)C)CC2</smiles>

Fig.-5: Alpha-Tocopherol-beta-D-mannoside

\section{CONCLUSION}

Methanol extract of Buni fruit seeds is classified as a very strong antioxidant with an $\mathrm{IC}_{50}$ of $11.632 \pm$ $0.280 \mathrm{mg} / \mathrm{L}$ and a Total Phenolic Content of $38.667 \pm 0.764 \mathrm{mg} / \mathrm{g}$ in GAE (Gallic Acid Equivalent). Methanol extract of Buni fruit seeds contains phenolic compounds in the form of Eugenol and AlphaTocopherol-beta-D-mannoside.

\section{ACKNOWLEDGEMENT}

Thanks to the Indonesian Ministry of Science, Technology and Higher Education for financial support and also to the Analytical Chemistry Division of the Bogor Agricultural University for collaborating with the author in conducting research studies.

\section{REFERENCES}

1. B. Dechayont, P. Hansakul and A. Itharat, Journal of the Medical Association of Thailand, 95, Suppl 1, 147 (2012).

2. M. Yasser, M. Rafi, W.T. Wahyuni, S.E. Widiyanti and A.M.I.A. Asfar, Rasayan Journal of Chemistry, 13 (1), 684 (2020), DOI:10.31788/RJC.2020.1315584 
RASĀYAN J. Chem.

Vol. 14 | No. 2 |1351-1355| April - June | 2021

3. R.C.M. Lizardo, L.B. Mabesa, E.I. Dizon and N.A. Aquino, International Food Research Journal, 22 (1), 88(2015).

4. S. Tawali, S. As'ad, M. Hatta, A. Bukhari, N. Khairi, Y. Rifai and R. Dwiyanti, Journal of Young Pharmacists, 11(1), 46 (2018), DOI:10.5530/jyp.2019.11.10

5. S. Jorjong, L. Butkhup and S. Samappito, Food Chemistry, 181, 284(2015), DOI: 10.1016/j.foodchem.2015.02.093

6. M. Yasser, M. Rafi, W.T. Wahyuni, A.M.I.A. Asfar and S.E. Widiyanti, Journal of Physics: Conference Series, 1655, 1(2020), DOI:10.1088/1742-6596/1655/1/012029

7. E. Bendary, R.R. Francis, H.M.G. Ali, M.I. Sarwat and S. El Hady, Annals of Agricultural Sciences, 58 (2), 173(2013), DOI: 10.1016/j.aoas.2013.07.002

8. J.Q. Quiroz, A.M.N. Duran, M.S. Garcia, G.L.C. Gomez and J.J.R. Camargo, International Journal of Food Science, 2019, 5 (2019), DOI:10.1155/2019/3721828

9. H.Y. Cui, H.N. Murthy, S.H. Moh, Y.Y. Cui, E.J. Lee and K.Y. Paek, CyTA - Journal of Food, 12(4), 355 (2014), DOI: 10.1080/19476337.2014.888482

10. C. Xu, Z. Liang, D. Tang, T. Xiao, M. Tsunodo, Y. Zhang, L. Zhao, S. Deng and Y. Song, Journal of Essential Oil Bearing Plants, 20(6), 1536(2017), DOI:10.1080/0972060X.2017.1417746

11. I. Matulyte, M. Marksa, L. Ivanauskas, Z. Kalveniene, R. Lazauskas and J. Bernatoniene, Molecules, 24(6), 2(2019), DOI:10.3390/molecules 24061062

12. A. Wahyono, A.C. Dewi, S. Oktavia, S. Jamilah and W.W. Kang, IOP Conference Series: Earth and Environmental Science, 411(1), 1(2020), DOI:10.1088/1755-1315/411/1/012049

13. A. Simamora, A.W. Santoso, K.H. Timotius and I. Rahayu, International Journal of Food Science, 2020, 1 (2020), DOI: $10.1155 / 2020 / 3436940$

14. J. Sukweenadhi, O, Yunita, F. Setiawan, Kartini, M.T. Siagian, A.P. Danduru and C. Avanti, Biodiversitas, 21(5), 2062(2020), DOI:10.13057/biodiv/d210532

15. M. Manssouri, M. Znini and L. Majidi L, Journal of Taibah University for Science, 14(1), 124(2020), DOI: 10.1080/16583655.2019.1710394

16. A.B.D. Nandiyanto, R. Oktiani and R. Ragadita, Indonesian Journal of Science \& Technology, 4(1), 97(2019), DOI:10.17509/ijost.v4i1.15806

17. J. Coates, Encyclopedia of Analytical Chemistry, John Wiley \& Sons, Ltd, New York, USA, p. 8-14 (2006), DOI:10.1002/9780470027318.a5606

18. S. Diblan, P. Kadiroglu and L.Y. Aydemir, Food and Health, 4(2), 80(2018), DOI:10.3153/FH18008

19. D.P. Bezerra, G.C.G. Militão, M.C. De Morais and D.P. De Sousa, Nutrients, 9(12), 1 (2017), DOI: $10.3390 /$ nu9121367

20. A.P. Arrozi, S.N.S. Shukri, W.Z.W. Ngah, Y.A.M. Yusof, M.H.A Damanhuri, F. Jaafar and S. Makpol, Scientific Reports, 10(1), 1(2020), DOI:10.1038/s41598-020-65570-4

21. V.A.R. Fernandes, R.O.R.F. Netto, F.L. Belozo and E.J. Caldeira, Romanian Journal of Diabetes Nutrition and Metabolic Diseases, 27(3), 274(2020), DOI:10.46389/rjd-2020-1040

22. K.N. Engin, Molecular Vision, 15, 855 (2009).

23. E. Makuch, A. Nowak, A. Günther, R. Pelech, L. Kucharski, W. Duchink and A. Klimowicz, AMB Express, 10(187), 1(2020), DOI:10.1186/s13568-020-01122-3

24. I. Gülçin I, Journal of Medicinal Food, 14(9), 975(2011), DOI:10.1089/jmf.2010.0197

25. J. Kaur and S. Kaushal, Journal of Essential Oil Bearing Plants, 23(2), 230(2020), DOI: 10.1080/0972060X.2020.1759458

26. F.N. Alfikri, R. Pujiarti, M.G. Wibisono and E.B. Hardiyanto, Scientifica, 2020, (2020), DOI: $10.1155 / 2020 / 9701701$

27. F. Utari, A. Itam, Syafrizayanti and M. Efdi, Rasayan Journal of Chemistry, 13(2), 796(2020), DOI: $10.31788 /$ RJC.2020.1325547

28. A.R. Prihadi, A. Maimulyanti, B. Mellisani and Nurhasanah, Rasayan Journal of Chemistry, 13(2), 253(2020), DOI: 10.31788/RJC.2020.1325613

29. S. Khomdram, S. Arambam, S. Barthakur and G.S. Devi,. International Journal of Current Microbiology and Applied Sciences, 6(4), 253(2017), DOI:10.20546/ijcmas.2017.604.029

[RJC-6288/2020] 